\title{
Masalah Psikologis dan Terapinya dalam Novel Moga Bunda Disayang Allah Karya Tere Liye
}

\author{
Detty Kurniawati Saputri \\ Universitas Indraprasta PGRI \\ Jalan Nangka No. 58 C/TB. Simatupang, Tanjung Barat, Jakarta Selatan 12530 \\ dettypurple@gmail.com
}

\begin{abstract}
This study aims to find out the characters who experience psychological problems and therapies that are carried out to overcome psychological problems in the novel Moga Bunda Disayang Allah by Tere Liye. Research uses qualitative methods. The results of his research were figures from Melati, Karang, Bunda HK, and Mr. HK having psychological problems. Therapy is done to overcome psychological problems namely Occupational Therapy, Biomedicine, and Applied Behavior Analysis. The therapy that is commonly found in the novel is occupational therapy.
\end{abstract}

Keywords: Psychological Problems, Therapy, Novels.

\begin{abstract}
Abstrak
Penelitian ini bertujuan untuk mengetahui tokoh-tokoh yang mengalami masalah psikologis dan terapi yang dilakukan untuk mengatasi masalah psikologis dalam novel Moga Bunda Disayang Allah karya Tere Liye. Penelitian menggunakan metode kualitatif. Hasil penelitiannya adalah tokoh Melati, Karang, Bunda HK, dan Tuan HK mengalami masalah psikologis. Terapi yang dilakukan untuk mengatasi masalah psikologis yaitu terapi okupasi, biomedik, dan applied behavior analysis. Terapi yang banyak ditemukan dalam novel tersebut yaitu terapi okupasi.
\end{abstract}

Kata Kunci: Masalah Psikologis, Terapi, Novel

\section{PENDAHULUAN}

Novel sangat digemari oleh pembaca karena sebagian besar novel mengisahkan kehidupan manusia, dari novel tersebut kita dapat mempelajari nilainilai yang positif dalam kehidupan sehari-hari. Hal itu sesuai dengan pendapat Retnoningsih (2008: 338) bahwa novel adalah karangan atau prosa panjang yang mengandung rangkaian cerita kehidupan seseorang dengan orang-orang di sekelilingnya. Begitu pula Nurgiyantoro (2012:10), mengemukakan bahwa novel adalah sebuah cerita yang panjang, katakanlah berjumlah ratusan halaman jelas tak dapat disebut sebagai cerpen, melainkan lebih tepat sebagai novel.

Novel memiliki nilai kognitif dari segi psikologisnya. "Novel dapat mengajarkan lebih banyak tentang sifat-sifat manusia daripada psikolog" (The novelis can teach you more about human nature than the psychologist). Itu adalah pernyataan yang sering kita dengar (Wellek \& Warren, 2016:27).

Novel Moga Bunda Disayang Allah adalah novel Tere Liye kedua puluh lima yang mendapat sambutan baik dari masyarakat. Novel tersebut mempunyai ciri khas, yaitu mengisahkan kesedihan, keharuan, bahkan kematian yang dialami

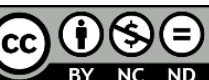

Creative Commons Attribution-NonCommercial-NoDerivatives 4.0 International License 
para tokohnya. Meskipun Tere Liye seorang laki-laki, tetapi ia mampu menyelami perasaan dan isi hati seorang wanita secara mendetail.

Psikologi berasal dari Bahasa Yunani yaitu psyche yang artinya jiwa, dan logos yang artinya ilmu pengetahuan. Jadi, secara etimologi psikologi berarti ilmu yang mempelajari jiwa, baik megenai macam-macam gejalanya, prosesnya, maupun latar belakangnya (Ahmadi, 2009:1).

Sarlito (2010: 1) menyatakan bahwa psikologi berasal dari kata-kata Yunani: Psyche yang berarti jiwa dan logos yang berarti ilmu. Jadi, secara harfiah psikologi berarti ilmu jiwa. Senada dengan John Broadus Watson dalam buku Psikologi Umum (Ahmadi, 2009:3) memandang psikologi sebagai ilmu pengetahuan yang mempelajari tingkah laku lahiriah dengan menggunakan metode observasi yang objektif terhadap rangsangan dan jawaban (respons).

Aryoso (2013:552) menyatakan bahwa terapi adalah usaha untuk memulihkan kesehatan orang yang sedang sakit. Senada dengan Aryoso, Retnonigsih (2005:560) menyatakan bahwa terapi adalah usaha untuk memulihkan kesehatan orang yang sedang sakit, pengobatan penyakit, perawatan penyakit. Wiyono (2007:599) menyatakan bahwa terapi adalah usaha untuk memulihkan kesehatan orang yang sedang sakit, pengobatan penyakit, perawatan penyakit.

Metode penanganan tingkah laku yang paling populer di Indonesia adalah appalied behavior analysis (ABA) yang dikembangkan oleh Ivar Lovaas. Penggunaan metode ini didasarkan pada aturan yang jelas dan sesi yang diulang untuk mencapai keterampilan (Indrastuti, 2013: 19).

Metode ABA yang tegas dan tanpa kekerasan ini sangat baik bila diterapkan kepada anak-anak dengan kelainan perilaku lainnya, bahkan anak normal (Handojo, 2009: 3).

Applied Behavioral Analysis (ABA) adalah metode yang dilakukan dengan memberi pelatihan khusus pada anak dengan memberikan positive reinforcement (hadiah atau pujian). Terapi ini diharapkan menambah keyakinan dan kepercayaan dirinya supaya dia dapat menerima keadaan dunia apa yang terjadi pada dirinya (Meranti, 2013:34).

Biomedik dikembangkan oleh kelompok dokter yang tergabung dalam DAN (Defeat Autism Now). Banyak dari perintisnya yang mempunyai anak autis. Mereka bekerja keras untuk meneliti dan menemukan bahwa gejala-gejala anak autis diperparah dengan adanya gangguan metabolisme yang akan berdampak pada gangguan fungsi otak (Meranti, 2013:42)

Penelitian yang dilakukan oleh Shattock menunjukkan bahwa gangguan pencernaan merupakan salah satu faktor penyebab munculnya gejala autisme. Sebagian besar anak autis memiliki struktur usus yang abnormal sehingga tidak mampu mengolah protein dari makanan yang mengandung susu dan gandum (Indrastusi, 2013:20).

Menurut Dr. Sasanti Yuniar (dalam Indrastuti, 2013:20), pakar psikiater anak menjelaskan bahwa untuk memperbaiki gangguan autisme dapat dilakukan dengan:

a. Memperbaiki regulasi neurotisme, dengan pemberian psikofarmaka. 


\section{Diskursus: Jurnal Pendidikan Bahasa Indonesia}

Vol. 2, No. 2, Agustus 2019, pp. 145-151

p-ISSN: 2615-4935

e-ISSN: 2615-4943

b. Memperbaiki gangguan metabolisme, seperti memperbaiki kondisi dybiosis pada anak, pemberian suplemen yang sesuai dengan gangguan pada jalur-jalur metabolisme.

c. Mengatur makanan, seperti mengurangi makanan gandum, MSG, zat pewarna dan lain-lain.

d. Memberikan antioksidan.

Sebagian besar anak autis mengalami keterlambatan dalam perkembangan motorik halusnya. Gerakan mereka terlihat kaku dan kasar. Bisanya mereka kesulitan untuk memegang pensil secara benar, kesulitan memegang sendok dan menyuapkan ke mulutnya, dan lain-lain. Oleh karena itu, dibutuhkan terapi okupasi yang bertujuan untuk melatih anak-anak autis menggunakan otot-otot halusnya dengan benar (Meranti, 2013: 38).

Terapi okupasi adalah terapi yang membantu individu dengan kelainan dan gangguan fisik, mental, maupun sosial dengan penekanan pada aspek sensomotorik dan proses neurologis (Manipuspika, 2011: 37).

Terapi okupasi berfokus pada kondisi anak, dilakukan melalui kegiatankegiatan yang menyenangkan dan pemberian dosis sensorik yang tepat. Dalam terapi integrasi sensorik psikolog bertugas membimbing anak untuk berpartisipasi secara aktif dalam berbagai kegiatan fisik yang memberi masukan sensorik untuk memperbaiki fungsi batang otak dan thalamus (Indrastuti, 2013: 21).

Berdasarkan latar belakang di atas, penelitian ini bertujuan untuk mengetahui masalah psikologis dan terapinya dalam novel Moga Bunda Disayang Allah karya Tere Liye.

\section{METODE}

Mengingat masalah yang diajukan, yaitu masalah psikologis dan terapinya dalam Novel Moga Bunda Disayang Allah, maka penelitian ini tercakup dalam penelitian metode kualitatif.

Menurut Sugiyono (2010:15) penelitian kualitatif adalah penelitian yang berlandaskan pada filsafat postpositivisme yang digunakan untuk meneliti pada kondisi objek yang alamiah, (yang bertolak belakang dengan eksperimen) di mana peneliti adalah sebagai instrumen kunci, pengambilan sampel sumber data dilakukan secara Purposive dan Snowball, teknik pengumpulan dengan triangulasi (gabungan), analisis data bersifat induktif/kualitatif, dan hasil penelitian kualitatif lebih menekankan makna daripada generalisasi.

Moleong (2011: 6) menjelaskan bahwa penelitian kualitatif adalah penelitian yang bermaksud untuk memahami fenomena tentang apa yang dialami oleh subjek penelitian misalnya perilaku, persepsi, motivasi, tindakan dan lain-lain.

Bogan dan Taylor (1975:5) dalam buku Metodologi Penelitian Kualitatif (Moleong, 2011: 4) menyatakan bahwa metodologi kualitatif sebagai sumber penelitian yang menghasilkan data deskriptif berupa kata-kata tertulis atau lisan dari orang-orang dan perilaku yang dapat diamati.

Sehubungan dengan tujuan khusus penelitian, maka peneliti memfokuskan penelitian ini pada masalah psikologis dan terapinya dalam novel Moga Bunda

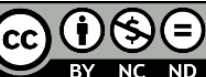

Creative Commons Attribution-NonCommercial-NoDerivatives 4.0 International License 
Disayang Allah Karya Tere Liye. Subfokus masalah psikologis terdiri dari tokoh yang mengalami psikologis dan tokoh yang membantu mengatasi masalah psikologis. Subfokus terapinya yang terdiri dari appalied behavior analysis, biomedik, dan okupasi dalam novel Moga Bunda Disayang Allak karya Tere Liye.

Teknik pengumpulan data merupakan langkah yang paling utama dalam penelitian, karena tujuan utama dari penelitian adalah mendapatkan data. Tanpa mengetahui teknik pengumpulan data, maka peneliti tidak akan mendapatkan data yang memenuhi standar data yang ditetapkan (Sugiyono, 2015: 308). Beberapa langkah dalam pengumpulan data dilakukan melalui tahapan-tahapan sebagai berikut:

1. Membaca novel Moga Bunda Disayang Allah karya Tere Liye secara berulangulang, sehingga peneliti memahami isinya secara keseluruhan.

2. Membaca secara teliti untuk mendapatkan masalah psikologis yang terdapat dalam novel Moga Bunda Disayang Allah karya Tere Liye.

3. Membaca secara teliti untuk mendapatkan terapi yang terdapat dalam novel Moga Bunda Disayang Allah karya Tere Liye.

4. Menguraikan masalah psikologis dan terapinya yang terdapat dalam novel Moga Bunda Disayang Allah karya Tere Liye.

5. Menjelaskan hasil penelitian secara menyeluruh berdasarkan data yang didapat.

6. Membuat simpulan dan menghubungkan novel dengan analisis tiap tataran.

Instrumen dalam penelitian ini menggunakan uraian masalah psikologis yang terdiri dari tokoh yang mengalami masalah psikologis dan tokoh yang membantu mengatasi masalah psikologis. Terapi psikologis yang terdiri dari applied behavioral analysis, biomedik, dan okupasi. Jumlah kutipan pada teks serta dalam menunjukkan seberapa besar intensitas pemunculan masing-masing unsur yang terdapat dalam novel Moga Bunda Disayang Allah karya Tere Liye. Data dianalisis dengan fokus pada masalah psikologis dan terapinya.

Sugiyono (2010: 335) menyatakan bahwa teknik analisis data kualitatif bersifat induktif yaitu suatu analisis berdasarkan data yang diperoleh, selanjutnya dikembangkan pola hubungan tertentu atau menjadi hipotesis. Berdasarkan hipotesis yang dirumuskan berdasarkan data tersebut, selanjutnya dicarikan data lagi secara berulang-ulang sehingga selanjutnya dapat disimpulkan apakah hipotesis tersebut diterima atau ditolak berdasarkan data yang dapat dikumpulkan secara berulang-ulang dengan teknik triangulasi, ternyata hipotesis diterima, maka hipotesis tersebut berkembang menjadi teori.

Moleong (2011: 248) menyatakan bahwa teknik analisis data kualitatif adalah mengemukakan proses dan menjelaskan tentang komponen-komponen yang perlu ada dalam suatu analisis data.

Bogdan dan Biklen (1982) dalam buku Metodotologi Penelitian Kualitatif (Moleong, 2011: 248) menyatakan bahwa teknik analisis data kualitatif adalah upaya yang dilakukan dengan jalan bekerja dengan data, mengorganisasikan data, memilah-milahnya menjadi satuan yang dapat dikelola, menyintesiskan, mencari dan menemukan pola, menemukan apa yang penting dan apa yang dipelajari, dan memutuskan apa yang dapat diceritakan. Keabsahan data dilakukan dengan berbagai teknik antara lain sebagai berikut: 
1. Menggunakan teknik triangulasi yaitu teknik pengujian kredibilitas, ini diartikan sebagai pengecekan data dari berbagai sumber dengan berbagai cara dan waktu.

2. Merangkum pendapat para ahli yang terdiri dari parameter, dosen-dosen pembimbing, dan teman-teman peserta seminar dalam hasil penelitian terhadap temuan penelitian.

3. Ketekunan pengamatan yaitu pengamatan yang mendalam tentang informasi data dari triangulasi, mencari informasi-informasi yang relevan tentang aspek yang diteliti.

\section{HASIL DAN PEMBAHASAN}

Masalah psikologis dan terapinya dalam novel Moga Bunda Disayang Allah karya Tere Liye menggunakan metode kualitatif. Berdasarkan analisis tokoh, novel tersebut menunjukkan tokoh Melati banyak terlibat dalam masalah psikologis dan terapinya.

Tokoh Melati lebih dominan dalam masalah psikologis karena memiliki keterbatasan dalam melihat, mendengar, dan berbicara. Sehingga, tidak bisa mengenal dunia dan seisinya. Bahkan, ia tidak mengenal Tuhan, Ayah, dan Bundanya.

Melati yang bisu dan tuli tidak dapat mengetahui bagaimana ia berekspresi, tata cara makan, dan apa yang harus dilakukan. Semua akses untuk mengenal dunia dan seisinya tertutup sehingga perilaku Melati ketika merasa disakiti oleh orang lain hanya berteriak, menghentak-hentakan kaki, memukul barang, atau orang.

Tokoh Karang yang memiliki sikap penyayang dan tanggung jawab terhadap anak-anak. Namun, karena tragedi ombak besar ia menjadi sosok yang idealis dan kasar. Karang tidak memiliki pendidikan akademis sehingga mendidik Melati sesuai dengan intuisinya. Ia membanting, mencengkeram, dan menghukum Melati dengan tidak memberikan sarapan. Tuan HK selaku ayah dari Melati tidak tega jika anaknya diperlakukan seperti itu apalagi dia adalah seorang pemabuk. Karena memiliki rasa tanggung jawab yang tinggi Karang tetap membantu Melati untuk bisa mengenal dunia dan seisinya. Trauma Karang sembuh ketika melihat tatapan Bunda HK yang putus harapan karena kondisi Melati yang tak kunjung sembuh. Karang berjanji untuk tidak mabuk-mabukan lagi.

Sikap Bunda HK yang sabar, optimis, dan putus asa dalam kesembuhan Melati. Berbagai cara yang dilakukan olehnya tidak membuahkan hasil. Bunda HK tidak tega terhadap Melati karena Karang mendidiknya dengan cara yang kasar. Namun, ketika melihat kemajuan Melati yang sudah bisa makan menggunakan sendok dan duduk di kursi, Bunda HK menjadi optimis bahwa Melati pasti sembuh.

Tuan HK memiliki sikap yang tegas karena ia menyayangi anaknya dan tidak ingin disakiti oleh orang lain. Cara Karang yang mendidik Melati dengan kasar, Tuan HK mengetahui masa lalu Karang yang seorang pemabuk, dan tuduhan pengadilan yang menyatakan 18 siswa taman bacaan meninggal saat tragedi ombak. Kemudian Karang diusir dari rumah Tuan HK.

Usaha Tuan, Bunda HK, Kinasih, Karang, dan dokter dalam kesembuhan

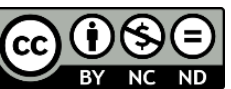

Creative Commons Attribution-NonCommercial-NoDerivatives 4.0 International License 
Melati dengan cara memanggil dokter dari Singapura dan Jerman. Namun, Bunda HK menolaknya karena terakhir diperiksa oleh tim dokter Melati dinyatakan gila sehingga, Bunda HK percaya bahwa Karang bisa membantu Melati.

Terapi appalied behavior analysis (ABA), cara Bunda HK memberikan pujian kepada anak semata wayangnya yang cantik dan Karang memberikan boneka Panda. Boneka itu milik Qintan. Karang memberikan boneka Panda kepada Melati karena Melati dan Qintan sama-sama memiliki keterbatasan. Qintan yang berjalan menggunakan tongkat, sedangkan Melati tidak melihat, mendengar, dan berbicara.

Terapi okupasi dalam novel Moga Bunda Disayang Allah lebih dominan karena Karang mendidik Melati agar makan dengan menggunakan sendok, tetapi cara ini direspons kurang baik oleh Melati. Melati berteriak, menggerung, dan berontak ketika makannya dibenarkan oleh Karang.

Karang melakukan berbagai cara demi kesembuhan Melati. Suatu ketika Melati diajarkan untuk mengenal nama-nama benda, benda tersebut pecah dan terinjak. Melati sangat merasa kesakitan. Namun, dari kejadian tersebut Karang tak menyadari bahwa alat peraba Melati masih berfungsi.

Karang merasa ada keanehan ketika Melati bisa mengetahui dimana keberadaan Karang. Kemudian, Karang memperkenalkan Melati dengan sebuah celengan, tetapi kali ini ia tidak dimarahi, justru Karang memberikan celengancelengan yang baru kepada Melati.

Keajaiban datang menghampiri Melati ketika ia bermain air mancur. Melati bisa merasakan air melalui jemarinya, sesuai dengan intuisinya lantas Karang memegang tangan Melati dan menuliskan kata air. Melati tidak memberikan tindakan apa pun. Karang menulis ulang kata air di tangannya dan menyentuhkan ke mulut Karang. Melati langsung tersenyum. Kemudian Tuan dan Bunda HK menghampiri Melati dan Karang. Saat itulah, Melati mengenal Ayah, Bunda, Pak Guru, dan Air. Melihat kejadian tersebut Tuan HK bersikap baik terhadap Karang.

\section{SIMPULAN}

Tokoh yang mengalami masalah psikologis paling dominan yaitu tokoh Melati, ia memiliki keterbatasan fisik sehingga seluruh akses tertutup untuk mengenal dunia dan seisinya. Karang yang berusaha keluar dari rasa bersalahnya karena 18 siswa taman bacaannya meninggal karena tragedi ombak besar. Bunda HK yang selalu menginginkan Melati untuk sembuh meskipun tim medis menyatakan bahwa Melati membutuhkan rumah sakit jiwa. Tuan HK adalah seorang ayah yang tertutup dari lingkungan sekitar dan melihat seseorang dari masa lalunya.

Terapi yang dilakukan untuk mengatasi masalah psikologis dalam Novel Moga Bunda Disayang Allah karya Tere Liye, menggambarkan usaha-usaha yang dilakukan keluarga Tuan HK, Bunda HK, dan Karang untuk menyembuhkan Melati. Terapi okupasi yang paling banyak ditemukan dalam novel tersebut karena Karang mengajarkan nama-nama benda kepada Melati untuk melatih sensomotorik dan neurologisnya melalui indera perabanya. Terapi biomedik sedikit ditemukan, Bunda HK menolak jika anaknya diperiksa oleh tim dokter lagi karena terakhir 
diperiksa Melati dinyatakan gila. Terapi appalied behavior analysis (ABA) lebih sedikit ditemukan karena Bunda HK dan Karang yang memberi pujian dan hadiah kepada Melati. Meskipun Melati memiliki keterbatasan fisik.

\section{DAFTAR PUSTAKA}

Ahmadi, A. (2009). Psikologi Umum. Jakarta: Rineka Cipta

Aryoso, D. W., \& Syaiful, H. (2013). Kamus Pintar Bahasa Indonesia. Jakarta: Pustaka Makmur

Handojo. (2009). Autisme: Pada Anak. Jakarta: PT Bhuana Ilmu Populer

Indrastuti, O. (2013). Mengenal Autisme dan Penanganannya. Yogyakarta: Familia Liye, T. (2018). Moga Bunda Disayang Allah. Jakarta: Republika

Manipuspika, Y. S. (2011). Langkah Awal Berinteraksi dengan Anak Autis. Jakarta: Gramedia Pustaka Utama

Meranti, T. (2013). Psikologi Anak Autis. Yogyakarta: Familia

Moleong, L. J. (2011). Metodologi Penelitian Kualitatif. Bandung: PT Remaja Rosda karya

Nurgiyantoro, B. (2012). Teori Pengkajian Fiksi. Yogyakarta: Gadjah Mada University Press

Retnoningsih, A. \& Suharso. (2005). Kamus Besar Bahasa Indonesia. Semarang: Widya Karya

Sarlito, W. S. (2010). Pengantar Psikologi Umum. Jakarta: Rajawali Press

Sugiyono. (2010). Metode Penelitian Pendidikan: Pendekatan Kuantitatif, Kualitatif, dan R\&D. Bandung: Alfabeta

Sugiyono. (2015). Metode Penelitian Pendidikan: Pendekatan Kuantitatif, Kualitatif, dan R\&D. Bandung: Alfabeta

Wellek, R., \& Waren, A. (2016). Teori Kesusastraan. Jakarta: PT Gramedia Pustaka Utama

Wiyono, E. H. (2007). Kamus Bahasa Indonesia Lengkap. Surabaya: Palanta 